\title{
Study of Angiotensin Converting Enzyme Gene Polymorphism in Egyptian Type 2 Diabetes Mellitus with Diabetic Kidney Disease
}

\author{
Rizk A. El-baz' , Alaa M. Wafa ${ }^{2}$, El-Shaimaa Marrawan1, Ahmed Ragab A. El-Tawab ${ }^{3}$, \\ Zeinab Ibraheam Aly ${ }^{3}$ \\ ${ }^{1}$ Genetics Unit, Children Hospital, Mansoura University, Mansoura, Egypt \\ ${ }^{2}$ Diabetes \& Endocrine Unit, Internal Medicine Hospital Faculty of Medicine, Mansoura University, Mansoura, Egypt \\ ${ }^{3}$ Faculty of Science, Tanta University, Tanta, Egypt \\ Email: *dralaawafa@hotmail.com
}

How to cite this paper: El-baz, R.A., Wafa, A.M., Marrawan, El-Sh., El-Tawab, A.R.A., and Aly, Z.I. (2018) Study of Angiotensin Converting Enzyme Gene Polymorphism in Egyptian Type 2 Diabetes Mellitus with Diabetic Kidney Disease. International Journal of Clinical Medicine, 9, 629-643. https://doi.org/10.4236/ijcm.2018.98053

Received: July 3, 2018

Accepted: August 4, 2018

Published: August 7, 2018

Copyright $\odot 2018$ by authors and Scientific Research Publishing Inc. This work is licensed under the Creative Commons Attribution International License (CC BY 4.0).

http://creativecommons.org/licenses/by/4.0/

(c) (i) Open Access

\begin{abstract}
Objective: Diabetic kidney disease DKD (Diabetic nephropathy DN) is considered one of the chronic micro vascular complications of diabetes mellitus and considered the commonest cause leading to chronic renal failure and chronic renal dialysis. Genetic susceptibility has been implicated in DKD. The angiotensin converting enzyme (ACE) is one of the key roles in the renin angiotensin system cascade by converting angiotensin I to angiotensin II which plays a key role in regulation of blood pressure as well as electrolytes and fluid balance. This study addressed the association of (ACE) gene polymorphisms with DN in Egyptian (T2DM) patients. Methods: Our research comprised of 75 cases of T2DM with diabetic kidney disease, 100 cases of T2DM without DKD and 94 healthy volunteers. Different genotypes of ACE gene were determined by SSP-PCR analysis. Results: Gene polymorphism of ACE (DD, ID, II) in diabetic patient with DKD is $44 \%, 52 \%, 4 \%$ respectively and for T2DM individuals without DKD is $23 \%, 72 \%, 5 \%$ respectively. (DD) had significant higher frequencies in T2DM patients with DKD compared to those without DKD $(p<0.005)$ and (ID) had significant higher frequencies in T2DM without DKD $(\mathrm{p}<0.0001)$. These results indicated that there is an association between ACE gene polymorphisms and susceptibility of diabetic patients to be affected by diabetic kidney disease. Conclusion: From our results, we can conclude that genotype of ACE in Egypt DD is the genotype of cases diabetic kidney disease. So the presence of $\mathrm{D}$ allele has a significant relation with diabetic kidney disease. Our data confirm the role of ACE in its relationship with diabetic kidney disease in Egyptian type 2 diabetic patients.
\end{abstract}




\section{Keywords}

ACE Gene Polymorphism, Insertion/Deletion, Type 2 Diabetes Mellitus, T2DM, Diabetic Kidney Disease, Diabetic Nephropathy, Microvascular

Complications of Diabetes Mellitus

\section{Introduction}

Diabetic kidney disease DKD (Diabetic nephropathy DN) is a clinical syndrome characterized by persistent albuminuria $(>300 \mathrm{mg} / \mathrm{d}$ or $>200 \mu \mathrm{g} / \mathrm{min}$ ) that is confirmed on at least 2 occasions 3 - 6 months apart, progressive decline in the glomerular filtration rate (GFR) and elevated arterial blood pressure [1].

Diabetic kidney disease is considered one of the most common causes for chronic renal failure and chronic hemodialysis [2]. Moreover, DKD also was considered one of the micro vascular complications in diabetic individuals and one of the leading causes of high mortality among patients with diabetes [3]. There are different etiologies that carry major and a key role that affects onset and progression of $\mathrm{DKD}$, of these factors genetic predisposition and environmental circumstances. A genetic susceptibility, depends on familial clustering of DKD, has been implicated in different pathogenic background of DKD in T2DM individuals [4]. One possible genetic factor is the Angiotensin converting enzyme gene (ACE).

Gene insertion (I), deletion (D) polymorphism within the human ACE gene [5], shown to be associated with predisposition to emerging different T2DM complications, including diabetic eye disease [6] and DKD [7]. ACE possesses a crucial role in the regulation of conversion process of renin angiotensin system by controlling conversion angiotensin I to II [8].

Angiotensin II (Ang II) considered a very strong vasoconstriction factor of the systemic and the local blood pressure [9]. Ang II increases systemic and glomerular blood pressure, stimulates mesangial cell proliferation and tissue growth [10].

Several polymorphisms depend on the presence or absence of a 287 base pair sequence in intron 16, three main different genotypes homozygotes (DD, II) and heterozygote ID are found [11].

\section{Methodology}

\subsection{Aim of the Work}

The aim of our research was to check for the association of ACE gene polymorphisms with the susceptibility to Diabetic kidney disease in Egyptian individuals with T2DM.

\subsection{Subjects}

This research has included 175 subjects with type 2 Diabetes Mellitus. They were 
recruited from the Internal Medicine Hospital (Diabetes clinic), Mansoura University, Egypt in the period between May and December 2017. The ethics committee approved the study protocol and the study was carried out in accordance with the Declaration of Helsinki. Written informed consent was obtained from all the patients included in the study.

An inclusion criterion includes type 2 Diabetic patients fulfilling criteria of diabetic nephropathy. An exclusion criterion includes, Type 1 diabetes mellitus, gestational diabetes, secondary diabetes, associated autoimmune diseases, non diabetic kidney diseases, patients suffering from hematuria, acute infections particularly urinary tract infections, and pregnant females were excluded from the study.

Selected Diabetic patients divided into 2 groups according to the presence of nephropathy consists of 75 subjects affected with diabetes type 2 associated with DKD compared to 94 healthy volunteers. In the Type 2 diabetic patients affected with Diabetic kidney disease, the mean \pm SD age was $58.03 \pm 6.34$ ranges from 45 to 74 years. They were in the form of $38(50.7 \%)$ males and $37(49.3 \%)$ females. The other group was affected with diabetes type 2 without DKD ( $\mathrm{n}=$ 100 ), their mean \pm SD age was $52.1900 \pm 8.31901$ range from 34 to 75 years; the gender divided between 30 (30.0\%) males and 70 (70.0\%) (Table 1).

\section{Method}

All subjects were questioned about history of diabetes mellitus, hypertension, hypercholesterolemia, history of DKD in the first degree relatives. Regarding clinical examination, blood pressure, weight, heights were measured. Laboratory investigation was done and included detection of urinary albumin with the following cutoff values (microalbuminuria, (Albumin/creatinine ration (ACR) between $30-300 \mathrm{mg} / \mathrm{g}$ ) and macroalbuminuria, (ACR more than 300) (according to national kidney foundation), detection of Glycated hemoglobin (HbAlc), lipid profile (Table 2).

Table 1. Descriptive data of all studied cases of (T2DM with nephropathy, T2DM without nephropathy and healthy people) regarding their characteristics.

\begin{tabular}{cccc}
\hline & Groups & N & Mean \\
\hline Age & T2DM with neuropathy & 75 & $58.03 \pm 6.34$ \\
& T2DM without neuropathy & 100 & $52.1900 \pm 8.31901$ \\
Health control & 94 & $51.179 \pm 9.217$ \\
Sex & T2DM with neuropathy & Male & Female \\
& T2DM without neuropathy & $50.7 \%$ & $49.3 \%$ \\
Health Control & $30 \%$ & $70 \%$ \\
Body mass index & T2DM with neuropathy & $46.8 \%$ & $53.2 \%$ \\
$\left(\mathrm{~kg} / \mathrm{rn}^{2}\right)$ & Health control & 75 & $28.3 \pm 4.1$ \\
& & 100 & $28.6 \pm 5.2$ \\
\hline
\end{tabular}

Data are means and SD. 
Table 2. Descriptive data of the two groups (T2DM with nephropathy and T2DM without nephropathy) regarding clinical findings.

\begin{tabular}{|c|c|c|c|}
\hline Parameters & & Groups & Mean \pm SD \\
\hline \multirow{2}{*}{$\begin{array}{l}\text { duration of diabetes } \\
\text { (Years) }\end{array}$} & \multicolumn{2}{|c|}{ T2DM with neuropathy } & $14.85 \pm 5.032$ \\
\hline & \multicolumn{2}{|c|}{ T2DM without neuropathy } & $14.74 \pm 4.15$ \\
\hline \multirow{2}{*}{ HbAlc (\%) } & \multicolumn{2}{|c|}{ T2DM with neuropathy } & $8.4 \pm 1.2$ \\
\hline & \multicolumn{2}{|c|}{ T2DM without neuropathy } & $8.1 \pm 1.6$ \\
\hline \multirow{4}{*}{ Retinopathy } & T2DM with & Background & $52 / 75(69.33 \%)$ \\
\hline & neuropathy & Proliferative & $21 / 75(28 \%)$ \\
\hline & T2DM withou & Background & $18 / 100(18 \%)$ \\
\hline & neuropathy & Proliferative & $4 / 100(4 \%)$ \\
\hline \multirow{2}{*}{ Creatinine (mg/dl) } & \multicolumn{2}{|c|}{ T2DM with neuropathy } & $1.2 \pm 0.9$ \\
\hline & \multicolumn{2}{|c|}{ T2DM without neuropathy } & $0.8 \pm 0.2$ \\
\hline \multirow{2}{*}{ Cholesterol (mg/dl) } & \multicolumn{2}{|c|}{ T2DM with neuropathy } & $210.22 \pm 69.16$ \\
\hline & \multicolumn{2}{|c|}{ T2DM without neuropathy } & $155 \pm 44.32$ \\
\hline \multirow{5}{*}{ Triglyceride (TG, mg/dl) } & \multicolumn{2}{|c|}{ T2DM with neuropathy } & $140.97 \pm 88.60$ \\
\hline & \multicolumn{2}{|c|}{ T2DM without neuropathy } & $133 \pm 45.23$ \\
\hline & & Mild hypertension & $35(45.9 \%)$ \\
\hline & T2DM with & Moderate hypertension & $28(37.9 \%)$ \\
\hline & neuropathy & Severe hypertension & $8(10.8 \%)$ \\
\hline \multirow{5}{*}{ Blood Pressure } & & Normal & $4(5.4 \%)$ \\
\hline & & Mild hypertension & $31(31 \%)$ \\
\hline & T2DM & Moderate hypertension & $23(23 \%)$ \\
\hline & neuropathy & Severe hypertension & $9(9 \%)$ \\
\hline & & Normal & $37(37 \%)$ \\
\hline \multirow{2}{*}{$\begin{array}{l}\text { High density lipoprotein } \\
\text { (HDL, mg/dl) }\end{array}$} & \multicolumn{2}{|c|}{ T2DM with neuropathy } & $39.14 \pm 12.67$ \\
\hline & \multicolumn{2}{|c|}{ T2DM without neuropathy } & $42.11 \pm 6.32$ \\
\hline \multirow{2}{*}{$\begin{array}{l}\text { Low density lipoprotein } \\
\text { (LDL, mg/dl) }\end{array}$} & \multicolumn{2}{|c|}{ T2DM with neuropathy } & $144.35 \pm 63.21$ \\
\hline & \multicolumn{2}{|c|}{ T2DM without neuropathy } & $111.24 \pm 24.105$ \\
\hline \multirow{2}{*}{$\begin{array}{l}\text { Microalbuminuria/ } \\
\text { Macroalbuminuria }\end{array}$} & \multicolumn{2}{|c|}{ T2DM with neuropathy } & $20 / 42$ \\
\hline & \multicolumn{2}{|c|}{ T2DM without neuropathy } & - \\
\hline
\end{tabular}

Data are means and SD.

\subsection{DNA Extraction and Purification}

At first taking informed consent from all diabetic individuals included in our research and healthy volunteers, venous blood samples $(3 \mathrm{ml})$ were withdrawn and added on EDTA (ethylenediamine tetra acetate) containing tubes, DNA was extracted promptly using DNA extraction and purification kit (Gentra Systems, USA) according to manufacturer's instructions and then stored at $-20^{\circ} \mathrm{C}$ till use. 


\subsection{PCR Amplification}

ACE genotype analysis was performed by PCR-RFLP analysis.

Genomic DNA was isolated from peripheral blood leukocytes according to a standard salting out method [12]. Amplification was carried out in a DNA thermocycler (Eppendorf Master Cycler). First, PCR was performed using 20 pmoles of each primer (flanking primer pair): Sense oligo 5'-CTG GAG ACC ACT CCC ATC CTT TCT 3' and anti-sense oligo: 5'-GAT GTG GCC ATC ACA TTC GTC AGA T-3' in a final volume of $25 \mu$, containing $(0.5 \mu$ genomic DNA, $2 \mathrm{mM} \mathrm{Mgcl}_{2}, 50 \mathrm{mM} \mathrm{kcl}, 10 \mathrm{mM}$ Tris- $\mathrm{Hcl}$ ( $\mathrm{pH}=8.3$ ), $0.2 \mathrm{mM}$ of each $\mathrm{dNTP}$, and 0.5 unit of Taq polymerase. PCR was done with an initial denaturing time at $94^{\circ} \mathrm{C}$ for $1 \mathrm{~min}$. Then the DNA was amplified for 30 cycles with denaturation at $94^{\circ} \mathrm{C}$ for $30 \mathrm{~s}$, annealing at $58^{\circ} \mathrm{C}$ for $30 \mathrm{~s}$, and extension at $72^{\circ} \mathrm{C}$ for 1 min. This was followed by final extension at $72^{\circ} \mathrm{C}$ for $8 \mathrm{~min}$. PCR products were directly visualized using ethidium bromide staining after electrophoresis in a $2 \%$ agarose gel [13]. The amplification product is a $190 \mathrm{bp}$ fragment in the presence of the deletion (D) allele and a $490 \mathrm{bp}$ fragment in the presence of the insertion (I) allele. Therefore, there were three genotypes after electrophoresis: A $490 \mathrm{bp}$ band (genotype II), 190 bp band (genotype DD), or both 490 and 190 bp band (genotype ID). Mistyping of ID heterozygote as D homozygotes may occur. Thus, each sample that had the DD genotype was applied to PCR amplification using the forward: 5-TCG GAC CAC AGC GCC CGC CAC TAC-3'; and the reverse: 5'-TCG CCA GCC CTC CCA TGC CCA TAA-3' primers with identical PCR conditions except for an annealing temperature of $67^{\circ} \mathrm{C}$. The reaction yields a 335-bp amplicon only in the presence of an I allele, and no product for homozygous DD samples.

\section{Statistical Analysis}

Data were prepared and undergoing analysis through Statistical Package of Social Science (SPSS, version 10.0). The frequencies of different allelic polymorphisms of all studied individuals were compared between groups by using Fisher's exact test (modified Chi square test) and Odds ratio. A value of $\mathrm{p}<0.05$ was considered to be significant.

\section{Results}

Comparing studied cases of T2DM with nephropathy to that of T2DM without nephropathy regarding the gene polymorphism of ACE and alleles (Table 3, Figure 1 and Figure 2) showed that cases of T2DM with DKD had a statistically significant lower frequencies of the ID genotype and I allele compared to cases of T2DM without DKD (52.0\% vs. $72.0 \%, \mathrm{p}<0.0001$ and $30.0 \%$ vs. $41.0 \%, \mathrm{p}<$ 0.045 respectively) while they had a significantly very high frequency of the DD genotype and D allele ( $44.0 \%$ vs. $23.0 \%$, p $<0.005$ and $70.0 \%$ vs. $59.0 \%, \mathrm{p}<0.045$ respectively). On the other hand, II genotype had no significant frequency in cases of T2DM with nephropathy or cases of diabetes type II without nephropa- 
thy.

By comparing cases of T2DM without nephropathy versus healthy people (Table 4), had a significant lower frequency of genotype DD and allele D compared to healthy people $(23.0 \%$ vs. $48.9 \%, \mathrm{p}<0.0001$ and $59.0 \%$ vs. $71.8 \%, \mathrm{p}<$ 0.011 respectively), while they had a statistically significant very high frequency of ID \& I allele ( $72.0 \%$ vs. $45.7 \%, \mathrm{p}<0.0001,41.0 \%$ vs. $28.2 \%, \mathrm{p}<0.011$, respectively). But by Comparing cases of diabetes T2DM with nephropathy and healthy people had no significant frequency (Table 5).

Comparing cases albuminuria $>300$ with those $<300$ as regards the studied ACE gene polymorphisms, it is observed that cases $>300$ have high frequency of DD genotype $(45.2 \%$ vs. $30 \%, \mathrm{OR}=1.93, \mathrm{p}=0.75)$. Also cases $>300$ had low frequency of ID genotype ( $50 \%$ vs. $65 \%, O R=0.54, p=0.403$ ). Regarding the allele frequencies, the $\mathrm{D}$ allele showed higher level among cases with macroalbuminuria $(70.24 \%$ vs. $62.5 \%, \mathrm{OR}=1.42, \mathrm{p}=0.51)$, while the I allele showed lower level $(29.76 \%$ vs. $37.5 \%, \mathrm{OR}=0.71, \mathrm{p}=0.51)$ (Table 6$)$.

Comparing cases with blood pressure groups regards that the studied ACE gene polymorphisms, it is observed that in DD genotype normal have high level then sever then mild and moderate is the lower one $(75 \%, 50 \%, 44.1 \%, 39.3, \mathrm{p}=$ 0.232). In addition, in ID genotype found that moderate have higher level then mild then sever and normal is lower one $(57.1 \%, 52.9 \%, 50 \%, 0 \%, \mathrm{p}=0.232)$ (Table 7).

Comparing cases with hyperlipidemia with those without hyperlipidemia as regards the studied ACE gene polymorphisms, it is observed that cases with hyperlipidemia have high frequency of DD genotype $(46.2 \%$ vs. $44.7 \%$, OR $=$ $1.06, \mathrm{p}=0.903)$. In addition, cases with hyperlipidemia had high frequency of ID genotype $(53.8 \%$ vs. $48.9 \%, \mathrm{OR}=1.22, \mathrm{p}=0.874)$. Regarding the allele frequencies, the $\mathrm{D}$ allele showed higher level among cases with hyperlipidemia (46.2\% vs. $44.7 \%, \mathrm{OR}=1.06, \mathrm{p}=0.903)$, while the I allele showed lower level $(26.9 \%$ vs. $30.9 \%, \mathrm{OR}=0.83, \mathrm{p}=0.76$ ) (Table 8).

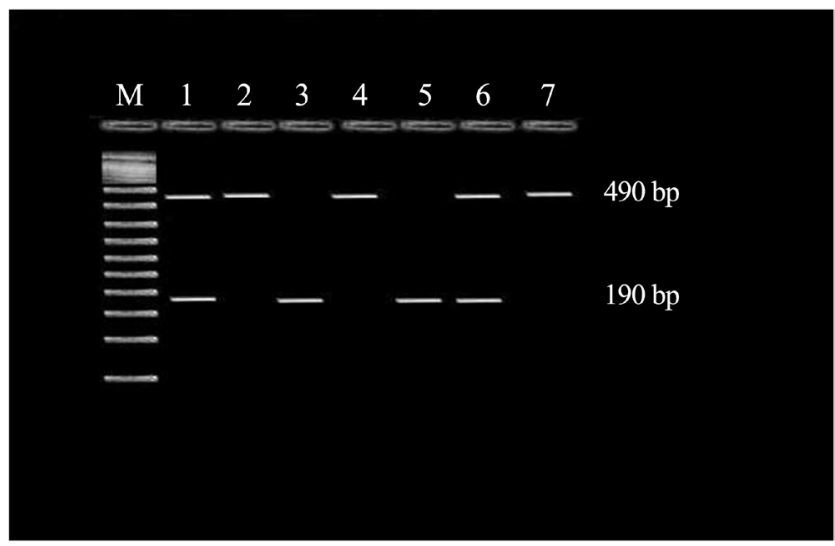

Figure 1. Detection of genetic polymorphism of ACE using PCR amplification: This figure showed 3 main different picture (DD, ID and II): DD homozygous (a single 190 base pair), ID heterozygous (190 and 490) Base pair, II homozygous (490 bp). 


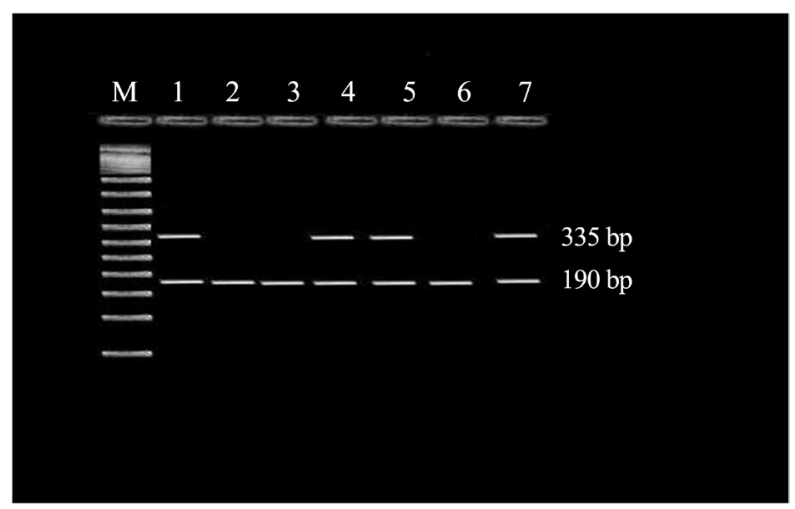

Figure 2. Second PCR amplification of ACE gene polymorphism: This figure shows, homozygous DD (a single $190 \mathrm{bp}$ product) and heterozygous ID (190 and 335 bp product).

Table 3. Comparison between T2DM subjects with nephropathy and T2DM subjects without nephropathy regarding the frequency of their allele and gene polymorphism of ACE.

\begin{tabular}{ccccc}
\hline & $\begin{array}{c}\text { Diabetic subjects with } \\
\text { nephropathy } \\
\mathrm{n}(\%)\end{array}$ & $\begin{array}{c}\text { Diabetic subjects } \\
\text { without } \\
\text { nephropathy } \\
\mathrm{n}(\%)\end{array}$ & $\chi^{2}(\mathrm{P})$ & OR $(95 \% \mathrm{CI})$ \\
\hline $\mathrm{N}=75$ & $\mathrm{~N}=100$ & & \\
\hline $\mathrm{DD}$ & $33(44.0)$ & $23(23.0)$ & $7.75(0.005)^{*}$ & $2.6(1.37-5.05)$ \\
$\mathrm{ID}$ & $39(52.0)$ & $72(72.0)$ & $13.32(<0.0001)^{* *}$ & $0.27(0.14-0.54)$ \\
$\mathrm{II}$ & $3(4.0)$ & $5(5.0)$ & $0.003(0.956)$ & $0.792(0.18-3.42)$ \\
Alleles & $\mathrm{N}=150$ & $\mathrm{~N}=200$ & & \\
$\mathrm{D}$ & $105(70)$ & $118(59)$ & $4.023(0.045)^{*}$ & $1.62(1.035-2.54)$ \\
$\mathrm{I}$ & $45(30)$ & $82(41)$ & $4.023(0.045)^{*}$ & $0.62(0.39-0.97)$ \\
\hline
\end{tabular}

Table 4. Comparison between cases T2DM without nephropathy and healthy volunteers regarding the frequency of their allele and gene polymorphism of ACE.

\begin{tabular}{ccccc}
\hline & $\begin{array}{c}\text { Diabetic subjects without } \\
\text { nephropathy } \\
\mathrm{n}(\%)\end{array}$ & $\begin{array}{c}\text { Healthy } \\
\text { subjects } \\
\mathrm{n}(\%)\end{array}$ & $\chi^{2}(\mathrm{P})$ & OR $(95 \% \mathrm{CI})$ \\
\hline $\mathrm{N}=100$ & $\mathrm{~N}=94$ & & \\
\hline $\mathrm{DD}$ & $23(23.0)$ & $46(48.9)$ & $13.11(<0.0001)^{* *}$ & $0.31(0.17-0.58)$ \\
$\mathrm{ID}$ & $72(72.0)$ & $43(45.7)$ & $12.77(<0.0001)^{* *}$ & $3.05(1.7-5.54)$ \\
$\mathrm{II}$ & $5(5.0)$ & $5(5.3)$ & $0.05(0.823)$ & $0.94(0.26-3.35)$ \\
Alleles & $\mathrm{N}=200$ & $\mathrm{~N}=188$ & & \\
$\mathrm{D}$ & $118(59)$ & $135(71.8)$ & $6.45(0.011)^{*}$ & $0.57(0.37-0.86)$ \\
$\mathrm{I}$ & $82(41)$ & $53(28.2)$ & $6.45(0.011)^{*}$ & $1.77(1.16-2.71)$ \\
\hline
\end{tabular}

$\mathrm{n}=$ number of cases, $(\%)=$ percentage of cases, Odds ratio \& $95 \%$ confidence interval $=\mathrm{OR}(95 \% \mathrm{CI}) .{ }^{*} \mathrm{p}<$ 0.05 (significant) ${ }^{* *} \mathrm{p}<0.001$ (extremely significant): Significance using Fisher's exact test. 
Table 5. Comparing between type 2 diabetes mellitus with nephropathy group and healthy control regarding their allele frequency and genotype distribution of ACE polymorphism.

\begin{tabular}{ccccc}
\hline & $\begin{array}{c}\text { T2DM with } \\
\text { Nephropathy } \\
\mathbf{n}=\mathbf{7 5}(\%)\end{array}$ & $\begin{array}{c}\text { Healthy } \\
\text { Control } \\
\mathbf{n}=\mathbf{9 4}(\%)\end{array}$ & $\mathrm{X}^{2}(\mathrm{p})$ & OR 95\% CI \\
\hline DD & $33(44.0)$ & $46(48.9)$ & $0.234(0.629)$ & $0.82(0.45-1.51)$ \\
I D & $39(52.0)$ & $43(45.7)$ & $0.43(0.51)$ & $1.29(0.7-2.4)$ \\
I I & $3(4.0)$ & $5(5.3)$ & $0.001(0.98)$ & $0.74(0.17-3.21)$ \\
Allele & $\mathrm{N}=150$ & $\mathrm{~N}=188$ & & \\
D & $105(70)$ & $135(71.8)$ & $0.059(0.808)$ & $0.92(0.57-1.47)$ \\
I & $45(30)$ & $53(28.2)$ & $0.059(0.808)$ & $1.092(0.68-1.75)$ \\
\hline
\end{tabular}

Comparing cases with diabetic nephropathy with those healthy controls as regards the studied ACE gene polymorphisms, it is observed that cases with nephropathy lower frequency of DD genotype, which was not significant from that of healthy controls ( $44 \%$ vs. $48.9 \%, \mathrm{OR}=0.82, \mathrm{p}=0.629)$. Also cases of nephropathy had higher frequency of ID genotype ( $52 \%$ vs. $45.7 \%, \mathrm{OR}=1.29, \mathrm{p}=0.51$ ). Regarding the allele frequencies the $\mathrm{D}$ allele showed lower level among cases diabetic nephropathy ( $70 \%$ vs. $71.8 \%, \mathrm{OR}=0.92, \mathrm{p}=0.808$ ), while the I allele showed higher level ( $30 \%$ vs. $28.2 \%, \mathrm{OR}=1.09, \mathrm{p}=0.059)$.

Table 6. Comparison between macroalbuminuric T2DM with nephropathy group and microalbuminuric T2DM with nephropathy group regarding their allele frequency and gene polymorphism of ACE.

\begin{tabular}{ccccc}
\hline & $\begin{array}{c}\text { Macroalbuminuria } \\
\mathrm{N}=42(\%)\end{array}$ & $\begin{array}{c}\text { Microalbuminuria } \\
\mathrm{N}=20(\%)\end{array}$ & $\mathrm{X}^{2}(\mathrm{p})$ & OR 95\% CI \\
\hline DD & $19(45.2)$ & $6(30.0)$ & $0.75(0.39)$ & $1.93(0.62-5.99)$ \\
I D & $21(50.0)$ & $13(65.0)$ & $0.7(0.403)$ & $0.54(0.18-1.62)$ \\
I I & $2(4.8)$ & $1(5.0)$ & $0.35(0.55)$ & $0.95(0.081-11.14)$ \\
Alleles & $\mathrm{N}=84$ & $\mathrm{~N}=40$ & & \\
D & $59(70.24)$ & $25(62.5)$ & $0.43(0.51)$ & $1.42(0.64-3.13)$ \\
I & $25(29.76)$ & $15(37.5)$ & $0.43(0.51)$ & $0.71(0.32-1.56)$ \\
\hline
\end{tabular}

Comparing cases albuminuria $>300$ with those $<300$ as regards the studied ACE gene polymorphisms, it is observed that cases $>300$ have high frequency of DD genotype ( $45.2 \%$ vs. $30 \%, \mathrm{OR}=1.93, \mathrm{p}=0.75)$. Also cases $>300$ had low frequency of ID genotype $(50 \%$ vs. $65 \%$, OR $=0.54, p=0.403)$. Regarding the allele frequencies, the $\mathrm{D}$ allele showed higher level among cases with macroalbuminuria $(70.24 \%$ vs. $62.5 \%$, $\mathrm{OR}=$ $1.42, \mathrm{p}=0.51)$, while the I allele showed lower level $(29.76 \%$ vs. $37.5 \%, \mathrm{OR}=0.71, \mathrm{p}=0.51)$.

Table 7. Comparing between blood pressure groups as regard ACE polymorphism in cases of diabetic nephropathy.

\begin{tabular}{cccccc}
\hline \multicolumn{5}{c}{ Blood. $\mathrm{p}$} & $\mathrm{X}^{2}(\mathrm{p})$ \\
\hline & Mild & Moderate & Severe & Normal & \\
& $\mathrm{N}=34(\%)$ & $\mathrm{N}=28(\%)$ & $\mathrm{N}=8(\%)$ & $\mathrm{n}=4(\%)$ & \\
\hline DD & $15(44.1)$ & $11(39.3)$ & $4(50.0)$ & $3(75.0)$ & \\
I D & $18(52.9)$ & $16(57.1)$ & $4(50.0)$ & $0(0)$ & $8.090(0.232)$ \\
I I & $1(2.9)$ & $1(3.6)$ & $0(0)$ & $1(25.0)$ & \\
\hline
\end{tabular}

Comparing cases with blood pressure groups regards that the studied ACE gene polymorphisms, it is observed that in DD genotype normal have high level then sever then mild and moderate is the lower one $(75 \%, 50 \%, 44.1 \%, 39.3, \mathrm{p}=0.232)$. In addition, in ID genotype found that moderate have higher level then mild then sever and normal is lower one $(57.1 \%, 52.9 \%, 50 \%, 0 \%, \mathrm{p}=0.232)$. 
Table 8. Comparing between cases with hyperlipidemia and without hyperlipidemia as regard ACE polymorphism.

\begin{tabular}{ccccc}
\hline & $\begin{array}{c}\text { With } \\
\text { Hyperlipidemia } \\
\mathrm{N}=26(\%)\end{array}$ & $\begin{array}{c}\text { Without } \\
\text { Hyperlipidemia } \\
\mathrm{N}=47(\%)\end{array}$ & $\mathrm{X}^{2}(\mathrm{p})$ & OR 95\% CI \\
\hline DD & $12(46.2)$ & $21(44.7)$ & $0.015(0.903)$ & $1.06(0.41-2.78)$ \\
I D & $14(53.8)$ & $23(48.9)$ & $0.025(0.874)$ & $1.22(0.47-3.18)$ \\
I I & $0(0)$ & $3(6.4)$ & $0.22(0.64)$ & $0.24(0.012-4.83)$ \\
Allele & $\mathrm{N}=52$ & $\mathrm{~N}=94$ & & \\
D & $38(73.1)$ & $65(69.1)$ & $0.096(0.76)$ & $1.21(0.57-2.57)$ \\
I & $14(26.9)$ & $29(30.9)$ & $0.096(0.76)$ & $0.83(0.39-1.75)$ \\
\hline
\end{tabular}

Comparing cases with hyperlipidemia with those without hyperlipidemia as regards the studied ACE gene polymorphisms, it is observed that cases with hyperlipidemia have high frequency of DD genotype (46.2\% vs. $44.7 \%, \mathrm{OR}=1.06, \mathrm{p}=0.903)$. In addition, cases with hyperlipidemia had high frequency of ID genotype ( $53.8 \%$ vs. $48.9 \%, \mathrm{OR}=1.22, \mathrm{p}=0.874)$. Regarding the allele frequencies, the $\mathrm{D}$ allele showed higher level among cases with hyperlipidemia $(46.2 \%$ vs. $44.7 \%, \mathrm{OR}=1.06, \mathrm{p}=0.903)$, while the I allele showed lower level $(26.9 \%$ vs. $30.9 \%, \mathrm{OR}=0.83, \mathrm{p}=0.76)$.

\section{Discussion}

There are several researches indicated that development and progression of diabetic kidney disease are multifactorial including different pathophysiologic mechanisms especially environmental or genetic susceptibility. Epidemiological studies found familial clustering of diabetic kidney disease in diabetic siblings, supporting an important role of genetic defects in the pathogenesis of diabetic kidney disease [14]. ACE is an enzyme (zinc metallopeptidase enzyme) that found to be highly expressed on the epithelial and endothelial surfaces. The function of ACE is to convert angiotensin I to angiotensin II that is the highly active biochemical end product of the rennin-angiotensin system (RAS) [15] and this associated with an increased risk of vascular disease [16]. Clinical studies investigated association between diabetic kidney disease and ACE gene polymorphism showed contradictory results.

This study included (269) 75 patients with diabetic kidney disease (DKD), 100 patients T2DM patients without DKD and 94 healthy people. In selection of cases, we were keeping to have cases affected with T2DM associated with diabetic kidney diseases. Their mean age was 58.02 years, with a SD of \pm 6.34 years. Out of them, $94.6 \%$ having hypertension, and $35.6 \%$ with hyperlipidemia and $22.5 \%$ have consanguinity and $72 \%$ have family history to diabetes. For comparison 100 cases diabetic (T2DM) without nephropathy (mean age was 51.7 years, with a SD of \pm 9.4 years) (Table 1 and Table 2 ).

This study showed that Egyptian cases of diabetic kidney disease had significantly higher frequency of genotype (DD) than cases diabetic with no DKD ( $44 \%$ versus $23 \%, p=0.005$ ). In addition, it's noticed that cases of diabetic nephropathy had significantly lower frequency of ID genotype than cases of diabetes without nephropathy ( $52 \%$ versus $72 \%, \mathrm{p}<0.0001)$ (Table 3 ). 
Diabetic nephropathy cases showed low frequency of II genotype than diabetic without nephropathy $5.3 \%$ ( $4 \%$ vs. $5 \%$ ). Meanwhile, total cases found to have statistically significant more frequent expression of D allele ( $70 \%$ vs. $59 \%, \mathrm{p}=$ 0.045) with a significant lower level of I allele than cases of diabetic without nephropathy ( $30 \%$ vs. $41 \%, p=0.045)$. Finally, in both group of cases and controls we observed that frequency D allele is higher than frequency of I allele.

In a previous study among Egyptian cases, reported that the II, ID and DD ACE genotypes was $4 \%, 52 \%$ and $44 \%$ in cases of diabetic nephropathy and $5 \%$, $72 \%$ and $23 \%$ in cases without nephropathy. The ACE DD genotype shows significant association with diabetic nephropathy. We can speculate that the difference may be related to the ethnic background variations between our locations in Egypt and other countries.

Analyzing the results among Egyptian controls, this study showed that Egypt control cases (diabetic without nephropathy) had a higher frequency of ID than that of DD genotype ( $72 \%$ vs. $52 \%)$ with a higher frequency of II genotype (5\% vs. $4 \%)$.

Also, our results showed that by comparing cases albuminuria $>300$ with those $<300$ as regards the studied ACE gene polymorphisms, it is observed that cases $>300$ have high frequency of DD genotype ( $45.2 \%$ vs. $30 \%, \mathrm{OR}=1.93, \mathrm{p}=$ $0.75)$. Also cases $>300$ had low frequency of ID genotype ( $50 \%$ vs. $65 \%$, OR $=$ $0.54, \mathrm{p}=0.403$ )

Regarding the allele frequencies, the $\mathrm{D}$ allele showed higher level among cases with macroalbuminuria $(70.24 \%$ vs. $62.5 \%, \mathrm{OR}=1.42, \mathrm{p}=0.51)$, while the I allele showed lower level ( $29.76 \%$ vs. $37.5 \%, \mathrm{OR}=0.71, \mathrm{p}=0.51)$ (Table 6). These results were in agreement with [17] who showed that females patients with abnormal excretion in urine (either micro or macro) found to have higher frequency of a genotype DD versus females with no albumin excreted in urine (DD $=27.9 \%, \mathrm{ID}=21.2 \%$ and $\mathrm{II}=10.5 \%$, respectively; $\mathrm{p} \leq 0.044)$ in Mexico population.

These findings are supported by study carried out in India population by [18] who demonstrated that the analysis of different genotype of ACE showed the following findings: genotype DD found in (22.75\%) cases with DKA, $15.42 \%$ in T2DM individuals, and $21.62 \%$ in healthy volunteers. Chi-square test between DKA group and healthy volunteers found to be non-significantly different in allele D. but, there is statistically significant difference $(\mathrm{p}<0.05)$ between patients with DKD and diabetic patients.

Regarding other micro vascular complications related to diabetic kidney disease [19] demonstrated that there was highly significant correlation between diabetic retinopathy and genotype DD. Their prevalence was found to be higher in individuals affected by genotype DD (DD, ID, and II, 90.4\%, 71.2\%, and 70.6\%; $\mathrm{p}<0.05$ respectively). individuals carry genotype $\mathrm{DD}$ reached the end point [s. creatinine levels more than $2.0 \mathrm{mg} / \mathrm{dL}$ (176.8 micromole/L)] more rapidly than individuals carry other different genotypes (DD, $11.38 \pm 4.08$ years; ID, $13.85 \pm$ 
4.04 years; II, $14.04 \pm 4.06$ years, respectively; $\mathrm{p}<0.05)$ and those individuals (with DD) was progressively reach to chronic hemodialysis earlier than others (DD, $13.10 \pm 4.45$ years; ID, $16.21 \pm 4.74$ years; II, $15.13 \pm 4.09$ years, respectively; $\mathrm{p}<0.05)$. Also, regarding hypertensive diabetic patients, there was a highly significant correlation between genotype DD and systolic blood pressure with progressive nature of Diabetic kidney diseases, in multiple logistic regression analysis.

Comparing cases with blood pressure groups regards that the studied ACE gene polymorphisms, it is observed that in DD genotype normal have high level then sever then mild and moderate is the lower one $(75 \%, 50 \%, 44.1 \%, 39.3 \%, \mathrm{p}$ $=0.232$ ). In addition, in ID genotype found that moderate have higher level then mild then sever and normal is lower one $(57.1 \%, 52.9 \%, 50 \%, 0 \%, \mathrm{p}=0.232$ ) (Table 7 and Figure 3).

In South Korea, subjects with genotype DD compared to others with genotype II, the OR was 3.881 (95\% confidence interval, 1.564 9.628; $\mathrm{p}=0.003$ approximately), these results indicated that the DD genotyping of ACE gene may be considered a significant risk factor for the progressive nature of diabetic kidney disease.

Also, [20] found that diabetic individuals with a high levels of insulin resistant states, diabetic kidney disease was represented in 2/11 diabetic individuals with ACE gene (II genotype) versus 19/25 diabetic individuals represented by DD or ID genotype $(\mathrm{p}=0.002)$. The prevalence of diabetic kidney disease was higher in the majority of individuals with both $\mathrm{D}$ allele plus significant insulin resistant states (19/25) compared to other patients (14. 37; OR, 5.20). These findings indicated that the ACE gene effectively can influence both onset and/or progressive nature of diabetic kidney disease in Japanese individuals with T2DM with high levels of insulin resistant state.

Also, in Tokyo, [21] concluded the following data, diabetic individuals with diabetic kidney disease have an excessive expression of genotype ID versus those individuals DKD $(\mathrm{p}<0.02)$ and less of the genotype II versus with healthy volunteers $(\mathrm{p}<0.01)$ and diabetic individuals without DKD $(\mathrm{p}<0.01)$. T2DM individuals presented with genotype II have a low risk for the development of diabetic kidney disease.

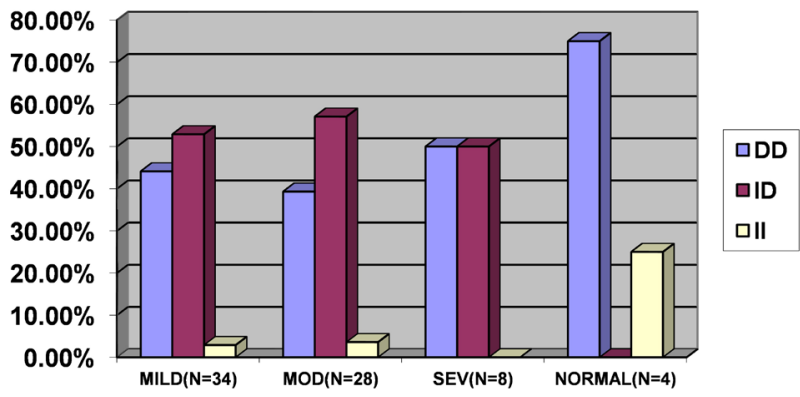

Figure 3. Comparing between blood pressure groups as regard ACE polymorphism in diabetic nephropathy cases. 
Also these findings were in contrast with [22] who found that the presentation of different genotypes (II, DD and DI) did not differ significantly between T2DM individuals with or without DKD (46\%; II: DD: 44\%; ID: $10 \%$ vs., II: $12 \%$, DD: 41\%; ID: 47\%; respectively). Also, no statistically any significantly different results between three main genotypes and allelic frequencies of the (I/D) polymorphism in all T2DM individuals versus healthy individuals with normal glycemic state (II: 11\%, ID: 46\%; DD: 43\%; vs. II: 15\%, DD: 37\%; ID: 48\%; respectively). So in Tunisian T2DM individuals, the (I/D) polymorphism within the ACE gene was found to be not associated with T2DM or DKD.

In addition, [23] showed that cases with DN incidence in T2DM individuals among three groups (II 45.8\%, ID 52.3\%, and DD 46.1\%, respectively, $\mathrm{p}>0.05$ ). The increased degree of urinary excretion of albumin among the 3 groups was similar at the end-point of the study $(\mathrm{p}>0.05)$. So, this study concluded that in china, genotype DD of ACE gene may not considered as genetic marker of clinical significance for prediction of the onset and progression of DKD in Type 2 diabetic patients in.

In addition, [24] found that there are no statistically differences in the mean eGFR according to different genotypes of ACE gene (ID: $99.5 \pm 25.1 \mathrm{ml} / \mathrm{min}$, II: $96.6 \pm 19.6 \mathrm{ml} / \mathrm{min}, \mathrm{DD}: 89.9 \pm 28.1 \mathrm{ml} / \mathrm{min}$ ). Also, they found no statistically significant changes in distribution of different genotypes diabetic individuals with different grades of albuminuria (DD:ID:II [\%], normoalbuminuric patients-35:46:19, macro albuminuric patients-31:55:14, microalbuminuric patients-28:55:17). So, they concluded that, in Turkey population, ACE gene polymorphism (D/I) found to be not to be associated with eGFR in T2DM individuals.

In addition, In Poland, [25] studied (No.941) cases with renal complication of T2DM diabetic individuals. Of them 127 diabetic individuals with macroalbuminuria or end stage renal disease, 335 diabetic individuals with microalbuminuria, and a control group of 254 diabetic individuals without albuminuria with duration of diabetic state of 10 years and more. They concluded that, there were no any statistically significant differences in the different genotype D/I distribution of ACE gene or allelic frequency was found in-between different tested groups. The conclusion of this research strongly found that there was no associated link between the ACE gene D/I polymorphisms and DKD in T2DM individuals.

In addition, In Germany, [26] concluded that genetic polymorphism D/I related to ACE gene does not significantly have a major role in the onset and progression of DKD.

Comparing cases with hyperlipidemia with those without hyperlipidemia as regards the studied ACE gene polymorphisms, it is observed that cases with hyperlipidemia have high frequency of DD genotype $(46.2 \%$ vs. $44.7 \%$, OR = $1.06, \mathrm{p}=0.903)$. In addition, cases with hyperlipidemia had high frequency of ID genotype ( $53.8 \%$ vs. $48.9 \%$, $\mathrm{OR}=1.22, \mathrm{p}=0.874$ ). 
Regarding the allele frequencies, the $\mathrm{D}$ allele showed higher level among cases with hyperlipidemia ( $46.2 \%$ vs. $44.7 \%, \mathrm{OR}=1.06, \mathrm{p}=0.903$ ), while the I allele showed lower level ( $26.9 \%$ vs. $30.9 \%, \mathrm{OR}=0.83, \mathrm{p}=0.76)$ (Table 8$)$.

Possible explanation of this controversy in the results of different researches related to genetic polymorphisms may be due to multifactorial aspects, mainly the major differences in ethnic aspects of studied diabetic individuals and healthy volunteers. Other factors include the definition of nephropathy or Diabetic kidney disease and inclusion criteria of the diabetic control group without renal complication and small sample sizes in some studies.

\section{Conclusion}

Our findings indicated that there is a strong relation between diabetic kidney disease and genetic polymorphism of ACE gene and from our results we also found that genotype of ACE in Egypt is DD genotype of diabetic cases with diabetic kidney disease so the presence of $\mathrm{D}$ allele has a significant relation with diabetic kidney disease. Our data confirm the significant role of angiotensin converting enzyme gene in its relationship with diabetic kidney disease risk in Egyptian population.

\section{Acknowledgements}

This research received no specific grant from any funding agency in the public, commercial, or not-for-profit sectors. All authors sharing in this manuscript have no conflicts of interest. All authors have contributed significantly, and that all authors are in agreement with the content of the manuscript.

\section{Conflicts of Interest}

The authors declare no conflicts of interest regarding the publication of this paper.

\section{References}

[1] Tang, S.C., Chan, G.C. and Lai, K.N. (2016) Recent Advances in Managing and Understanding Diabetic Nephropathy. F1000 Research, 5, 1000-1044. https://doi.org/10.12688/f1000research.7693.1

[2] Stephens, J.W. (2005) The D Allele of the ACE/ID Common Gene Variant Is Associated with T2D Mellitus in Caucasian Subjects. Molecular Genetics and Metabolism, 84, 83-88. https://doi.org/10.1016/j.ymgme.2004.09.002

[3] Chiarelli, F., Gaspari, S. and Marcovecchio, M.L. (2009) Role of Growth Factors in Diabetic Kidney Disease. Hormone and Metabolic Research, 41, 585-593. https://doi.org/10.1055/s-0029-1220752

[4] Sun, J., Xu, Y., Zhu, Y. and Lu, H. (2004) Genetic Polymorphism of Methylenetetrahydrofolate Reductase as a Risk Factor for Diabetic Nephropathy in Chinese Type 2 Diabetic Patients. Diabetes Research and Clinical Practice, 64, 185-190. https://doi.org/10.1016/j.diabres.2003.10.022

[5] Freedman, B.I., Bowden, D.W., Rich, S.S., Valis, C.J., Sale, M.M., Hicks, P.J., et al. (2005) A Genome Scan for All-Cause End-Stage Renal Disease in African Ameri- 
cans. Nephrology Dialysis Transplantation, 20, 712-718.

https://doi.org/10.1093/ndt/gfh704

[6] Parvanova, A., Iliev, I., Dimitrov, B.D., Arnoldi, F., Zaletel, J., Remuzzi, G. and Ruggenenti, P. (2002) Hyperhomocysteinemia and Increased Risk of Retinopathy: A Cross-Sectional, Case-Control Study in Patients with Type 2 Diabetes. Diabetes Care, 25, 2361. https://doi.org/10.2337/diacare.25.12.2361

[7] Mtiraoui, N., Ezzidi, I., Chaieb, M., Marmouche, H., Aouni, Z., Chaieb, A., Mahjoub, T., Vaxillaire, M. and Almawi, W.Y. (2007) MTHFR C677T and A1298C Gene Polymorphisms and Hyperhomocysteinemia as Risk Factors of Diabetic Nephropathy in Type 2 Diabetes Patients. Diabetes Research and Clinical Practice, 75, 99-106. https://doi.org/10.1016/j.diabres.2006.05.018

[8] Wang, F., Maggie, Y., Wing, N.S., et al. (2005) Prognostic Effect of Insertion/Deletion Polymorphism of the ACE Gene on Renal and Cardiovascular Clinical Outcomes in Chinese Patients with Type-2 Diabetes. Diabetes Care, 54, 301-306.

[9] Chang, H.R., Cheng, C.H., Shu, K.H., Chen, C.H., Lien, J.D. and Wu, M.Y. (2003) Study of the Polymorphism of Angiotensinogen, Angiotensin Converting Enzyme and Angiotensin Receptor in Type II Diabetes with End-Stage Renal Disease in Taiwan. Journal of the Chinese Medical Association, 66, 51-56.

[10] Klemm, T., Mittrach-Schorins, S., Neumann, S., Gerike, T., krankenberg, H., Schuler, G., et al. (2003) No Association between the Angiotensin-Converting-Enzyme Gene Insertion/Deletion Polymorphism and the Occurrence of Macroangiopaty in Patients with Diabetes Mellitus Type 2. Hormone and Metabolic Research, 35, 43-47. https://doi.org/10.1055/s-2003-38390

[11] Zhu, X., Chang, Y., Yan, D., Weder, A., Cooper, R., Luke, A., et al. (2003) Associations between Hypertension and Genes in the Rennin Angiotensin System. Hypertension, 41, 1027-1037. https://doi.org/10.1161/01.HYP.0000068681.69874.CB

[12] Miller, S.A., Dykes, D.D. and Polesky, H.F. (1988) A Simple Salting out Procedure for Extracting DNA from Human Nucleated Cells. Nucleic Acids Research, 16, 12-15. https://doi.org/10.1093/nar/16.3.1215

[13] Tanaka, C., Kamide, K., Takiachi, S., Miwa, Y., Yoshiim, M., Kawano, Y., et al. (2003) An Alternative Fast and Convenient Genotyping Method for the Screening of Angiotensin Converting Enzyme Gene Polymorphism. Hypertension Research, 26, 301-306. https://doi.org/10.1291/hypres.26.301

[14] Tanaka, N. and Babazono, T. (2005) Assessing Genetic Susceptibility to Diabetic Nephropathy. Nephrology, 10, S17-S21. https://doi.org/10.1111/j.1440-1797.2005.00451.x

[15] Erdös, E.G. and Skidgel, R.A. (1987) The Angiotensin I Converting Enzyme. Laboratory Investigation, 56, 345-348.

[16] Födinger, M., Hörl, W.H. and Sunder-Plassmann, G. (2000) Molecular Biology of 5,10-Methylenetetrahydrofolate Reductase. Journal of Nephrology, 13, 20-33.

[17] Palomo-Piñón, S., Gutiérrez-Rodríguez, M.E., Díaz-Flores, M., Sánchez-Barrera, R., Valladares-Salgado, A., Utrera-Barillas, D., Durán-Reyes, G., Galván-Duarte, R.E., Trinidad-Ramos, P. and Cruz, M. (2009) DD Genotype of Angiotensin-Converting Enzyme in Type 2 Diabetes Mellitus with Renal Disease in Mexican Mestizos. Nephrology (Carlton), 14, 235-239. https://doi.org/10.1111/j.1440-1797.2008.01034.x

[18] Movva, S., Alluri, R.V., Komandur, S., Vattam, K., Eppa, K., Mukkavali, K.K., Mubigonda, S., Saharia, S., Shastry, J.C. and Hasan, Q. (2007) Relationship of Angiotensin-Converting Enzyme Gene Polymorphism with Nephropathy Associated 
with Type 2 Diabetes Mellitus in Asian Indians. Journal of Diabetes and Its Complications, 21, 237-241. https://doi.org/10.1016/j.jdiacomp.2006.07.001

[19] Ha, S.K., Park, H.C., Park, H.S., Kang, B.S., Lee, T.H., Hwang, H.J., Kim, S.J., Kim, D.H., Kang, S.W., Choi, K.H., Lee, H.Y. and Han, D.S. (2003) ACE Gene Polymorphism and Progression of Diabetic Nephropathy in Korean Type 2 Diabetic Patients: Effect of ACE Gene DD on the Progression of Diabetic Nephropathy. American Journal of Kidney Diseases, 41, 943-949. https://doi.org/10.1016/S0272-6386(03)00191-4

[20] Kuramoto, N., Iizuka, T., Ito, H., Yagui, K., Omura, M., Nozaki, O., Nishikawa, T., Tsuchida, H., Makino, H., Saito, Y. and Kanatsuka, A. (1999) Effect of ACE Gene on Diabetic Nephropathy in NIDDM Patients with Insulin Resistance. American Journal of Kidney Diseases, 33, 276-281. https://doi.org/10.1016/S0272-6386(99)70300-8

[21] Mizuiri, S., Hemmi, H., Inoue, A., Yoshikawa, H., Tanegashima, M., Fushimi, T., Ishigami, M., Amagasaki, Y., Ohara, T., Shimatake, H., et al. (1995) Angiotensin-Converting Enzyme Polymorphism and Development of Diabetic Nephropathy in Non-Insulin-Dependent Diabetes Mellitus. Nephron, 70, 455-459. https://doi.org/10.1159/000188645

[22] Arfa, I., Abid, A., Nouira, S., Elloumi-Zghal, H., Malouche, D., Mannai, I., Zorgati, M.M., Ben, Alaya, N., Rebai, A., Zouari, B., Ben, Ammar, S., Ben, Rayana, M.C., Hmida, S., Blousa-Chabchoub, S. and Abdelhak, S. (2008) Lack of Association between the Angiotensin-Converting Enzyme Gene (I/D) Polymorphism and Diabetic Nephropathy in Tunisian Type 2 Diabetic Patients. Journal of the Renin-Angiotensin-Aldosterone System, 9, 32-36. https://doi.org/10.3317/jraas.2008.002

[23] Liao, L., Lei, M.X. and Chen, H.L. (2003) Angiotensin Converting Enzyme Gene Polymorphism and Type 2 Diabetic Nephropathy. Bulletin of Hunan Medical University, 28, 553-556.

[24] Araz, M., Aynacioglu, S., Okan, V., Akdemir, I., et al. (2002) Angiotensin-Converting Enzyme Gene Polymorphism and Coronary Heart Disease in Turkish Type 2 Diabetic Patients. Acta Cardiologica, 57, 265-269. https://doi.org/10.2143/AC.57.4.2005424

[25] Grzeszczak, W., Zychma, M.J., Lacka, B. and Zukowska-Szczechowska, E. (1998) Angiotensin I-Converting Enzyme Gene Polymorphisms: Relationship to Nephropathy in Patients with Non-Insulin Dependent Diabetes Mellitus. Journal of the American Society of Nephrology, 9, 1664-1669.

[26] Schmidt, S. and Ritz, E. (1997) Angiotensin I Converting Enzyme Gene Polymorphism and Diabetic Nephropathy in Type II Diabetes. Nephrology Dialysis Transplantation, 12, 37-41.

\section{Abbreviations}

T2DM: type 2 diabetes mellitus

DN: diabetic nephropathy

ACE: Angiotensin-converting enzyme

SSP-PCR: sequence specific primer-polymerase chain reaction 